\title{
Outlook for Farm Income and Food Prices ${ }^{1}$
}

\author{
by CLIFTON B. LUTTRELL
}

CCORDING to the United States Department of Agriculture both gross and net farm income will rise sharply this year. The physical volume of farm product sales will remain at about 1971 levels, but rising demand will cause prices to average somewhat higher. The slower growth in farm production will tend to reduce the rate of increase in food supplies, which along with rising food demand, points to higher average food prices than last year.

Realized net farm income in 1972 may exceed that of 1971 by 10 to 15 percent, according to the U. S. Department of Agriculture. Gross farm income is expected to rise $\$ 3$ to $\$ 3.5$ billion from the record $\$ 58.6$ billion in 1971 , and production expenditures may increase only $\$ 1$ to $\$ 1.5$ billion, resulting in a realized net income gain of $\$ 1.5$ to $\$ 2$ billion from the 1971 estimate of $\$ 15.7$ billion. This would be one of the largest annual income gains to farming in recent years. Average income per farm is expected to exceed $\$ 6,100$, a gain of 13 percent from a year earlier.

Most of the expected gain in gross farm income will be from increased receipts from livestock products and higher Government payments. Receipts from livestock product marketings may rise about $\$ 2$ billion from $\$ 29.7$ billion last year, and Government payments to farmers may rise $\$ 1.25$ billion from last year's $\$ 3.2$ billion. Crop receipts are expected to remain near their $\$ 21.9$ billion level of last year.

Total farm production expenditures may rise about $\$ 1.5$ billion, continuing their long trend upward, but at a slower rate than in most recent years. Since 1965 , such expenses have risen at the average rate of $\$ 2$ billion per year, reflecting both the uptrend in volume of production items used by farmers and a high rate of inflation. In the five years prior to 1965, at a time of little inflation, total farm production expense rose less than $\$ 1$ billion per year.

1The outlook portion of this article is a summary of the reports given at the $50 \mathrm{th}$ National Agricultural Outlook Conference in Washington, D. C., during the week of February $22,1972$.

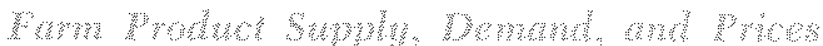

Little overall change in the physical volume of farm product sales is expected in 1972 from last year's levels. Total food output may be sufficient for per capita consumption to remain near 1971 record levels. After climbing for six consecutive years, the quantity of red meat supplied per capita this year may average slightly less than the 192 pounds in 1971. Beef output will be up moderately, partially offsetting some expected declines in veal, lamb, mutton, and some 4 to 5 pounds less pork per capita. Output of chicken will be sufficient to provide an increase in consumption from the record 41.6 pounds per person in 1971, but the gain may be smaller than in most recent years. Turkey production is expected to increase slightly from the 1971 level. Per capita supplies of red meat and poultry combined will thus remain near the levels of a year ago.

Egg output will likely be down from the relatively high levels of last year because of the recent decline in the laying flock. Although dairy product supplies are expected to rise, a portion of the increase will likely be removed from the market through Government price support operations.

Given normal weather conditions, crops will be in greater supply in 1972 than in 1971. Total processed vegetable stocks are slightly larger than a year ago. Winter and spring vegetable crops may increase slightly from last year's levels. Citrus crops may equal those of last year, but more efficient juice 
extraction methods may enhance the supply of citrus products. Potato stocks are down slightly from last year, but are about the average of recent years.

A large feed grain crop was produced in 1971 which, combined with a carryover from the previous year of 34 million tons, resulted in record feed grain stocks of 239 million tons. The resulting lower prices may lead to more liberal feeding, and total domestic feed grain usage this year may reach 184 million tons. Exports will probably total about 21 million tons, the same as a year ago. Carryover at the end of the current market year may total 55 million tons, up 22 million from last year and the largest volume of carry. over stocks since 1964.

The impact of the large quantity of feed grains on domestic food prices will, however, be redticed as a result of Government price support programs. The large stocks will tend to hold prices near the Govemment loan rate throughout the marketing year, thus preventing any major seasonal price increases. The Govermment price supports will prevent any major reductions. Government support prices for most grain crops in 1972 are unchanged from 1971 levels with the announced support prices: for corn, $\$ 1.08$ per bushel; oats, $\$ 0.54$ per bushel; and rye, $\$ 0.89$ per bushel. The support price for barley was raised from $\$ 0.81$ to $\$ 0.86$ per bushel.

Rice stocks are likewise in excess supply for the current marketing year beginning August 1, 1971 . Carryover stocks were up 13 percent from a year earlier, and coupled with the larger 1971 crop, resulted in a rice supply of 104.4 million cwt., about three times the expected domestic use for a year. Exports, however, may be up from the 46.5 million cwt. of last year, with most of the gain arising from subsidized export programs. Despite the excess stocks, prices will be supported by the Government at somewhat higher levels than last year, and cash receipts for the 1972 crop will likely be somewhat higher.

Wheat supplies are at the highest level in nine years as a result of the record 1971 harvest of 1,640 million bushels and the above average carryover stocks of 730 million bushels. The total supply of 2.4 billion bushels exceeds the previous year's level by 115 million bushels. Domestic wheat usage plus exports may total about 1.4 billion bushels, resulting in carryover stocks at the end of the current market season of almost one billion bushels - the largest carryover since 1963.

Wheat is grown under a two-tiered Government price support program - one price for wheat used for domestic food and the other for wheat used primarily for livestock feed and for export. The program for 1972 is little changed from that of a year earlier. The Government loan rate is $\$ 1.25$ per bushel, but the total support price for that portion of the crop used by the domestic food industry will be 100 percent of parity, or somewhat above the $\$ 2.93$ per bushel in 1971. The voluntary set-aside acreage for payment is up to 75 percent of domestic wheat allotments in 1972, whereas in 1971 there was no payment for voluntary set-aside acreage.

Soybean stocks are down from the 1970-71 total, and carryover into next year may be down to a minimum operating level. Stocks in the current marketing year total 1,268 million bushels compared with 1,354 million bushels a year earlier. Domestic crushings this year may not exceed 725 million bushels, down from 760 million last year, and exports are expected to be down somewhat from the 422 million bushels of a year earlier.

Soybean prices have risen sharply in recent weeks, and the price for the year is expected to average well above $\$ 3$ per bushel, the highest since 1947-48. With this increased price incentive, planting intentions are up. Even so, stocks are expected to remain relatively small for another year. The outlook is for relatively high prices for the 1972 crop and another gain in cash receipts from soybean sales.

Cotton planting restrictions have in recent years resulted in a relatively short supply. Smaller beginning stocks and below average production for the past two years may lead to the smallest stock of cotton in more than two decades. The 1971 crop of 10.4 million bales was only slightly above the previous year's crop and, with distribution for the two years totaling almost 23 million bales, carryover stocks at the end of the current year may not exceed 3.5 million bales. As a result, prices have increased sharply since mid-1971.

Cotton has for several decades faced intensive competition from man-made fibers. Domestic mill consumption in the calendar year 1971 totaled 19 pounds per person, down from 22 pounds in 1958. Its share of the fiber market slipped to 37 percent in 1971 , compared with 68 percent in 1958 . In contrast, man-made fiber usage reached a record high of 31.4 pounds per capita in 1971, or 61 percent of the fiber market, compared with 10 pounds per capita and 30 percent of the market in 1958.

Tobacco stocks, which like cotton are held in check by Government production control programs, are somewhat lower this marketing year than a year ago. 
The 1971 tobaceo crop was 6 percent less than a year earlier, and tobacco stocks, while still ample, are down 3 percent. This year's marketing quotas for flue-cured and burley tobacco are down 1 and 4 percent, respec. tively, from 1971 levels. Tobacco use has trended downward for several years, and this trend is likely to continue through the current marketing year. Prices received by farmers, however, are at record levels under the price support program, and the mandatory supports will be up 4.8 percent for this year's crop. Thus, cash receipts to growers are likely to rise somewhat.

Prices received by farmers for most products sold in early 1972 averaged well above those of early 1971 and are expected to remain above last year's levels throughout the year (see Table II). In January, average prices received were 13 percent above year earlier levels. By February, however, the gap between 1972 and 1971 prices narrowed to 9 percent as prices this year rose more slowly than last year. The year-toyear difference will likely remain below that of January throughout the remainder of 1972 .

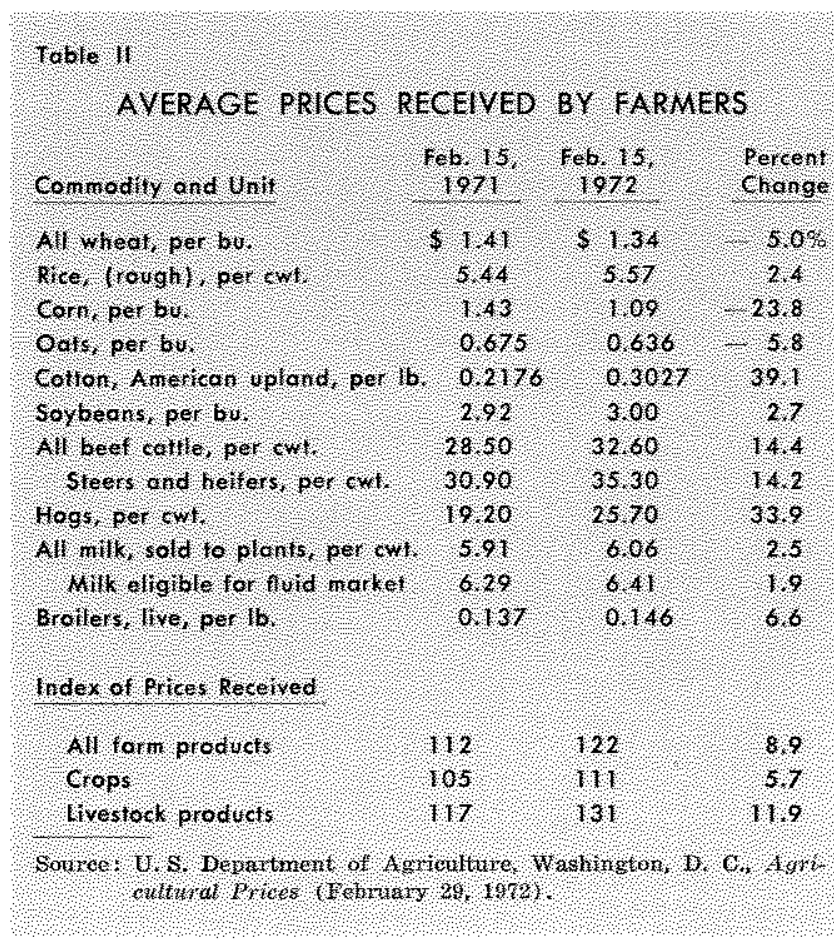

Meat animal prices this January averaged more than 25 percent above those of a year earlier, reflecting major increases in prices of hogs and beef cattle. Prices for hogs have declined from their relatively high January and February levels, but are expected to remain above last year's levels throughout the remainder of 1972 as a result of an expected reduction in per capita pork supplies. Beef prices are also likely to average higher than last year, but may decline later in the year if supplies increase as expected.

Milk prices may average above 1971 levels through the first quarter of the year, and broiler and egg prices will likely average higher than last year's levels throughout the year. On the other hand, prices of fresh fruits and vegetables, which have in recent months been far above year earlier levels, are expected to dip below 1971 levels since supplies will probably be larger than the freeze-damaged crops of early last year.

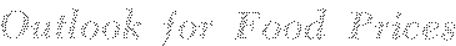

Rising private and Government demand for farm products and food and slower growth of the quantity available this year may cause food prices at grocery stores to average about 4 percent above the 1971. level. Much of the expected average increase in farm product prices for the year may have already occurred as a result of sharp increases for meat animals early in the year.

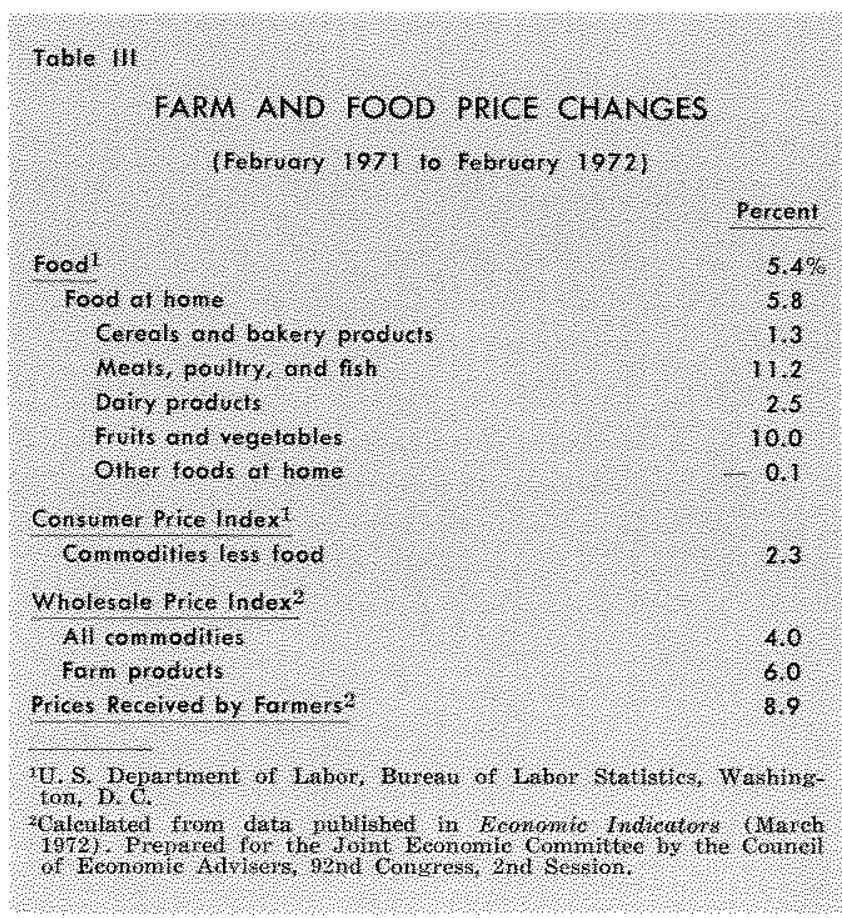

In contrast to a 9 percent rise in farm product prices, the average of all food prices rose only 5.4 percent and food at home rose 5.8 percent during the twelve months ending February 1972 (see Table III). The farmer's share of retail food cost likewise increased during the past year. During the twelve months ending November 1971, while farm prices were rising 7.5 percent, the farmer's share of retail food costs for urban workers rose from 36 to 39 per- 
cent. In the same period, the farm-retail spread portion of food cost rose less than one-tenth of a percent, despite a three to four percent general inflation." The deflated food processing and marketing margin thus actually declined, a movement which often occurs during periods of rapid increases in farm prices.

Meat, poultry, fish, fruit, and vegetable prices rose at substantially higher rates than the average for all foods in the year ending February 1972. Meats, poultry, and fish prices rose 11.2 percent, with most of the increase occurring in the last six months when prices of hogs and cattle were bid up to substantially higher levels. Fruit and vegetable prices rose 10 percent, with most of the gain occurring in the first half of the year because of the cold weather last winter and spring, which reduced supplies of vegetables and destroyed part of the citrus crop.

Ultimately, rising demand for food by consumers is reflected throughout the producing, processing, and distributing sectors. Thus, processing and marketing margins may rise further this year, offsetting the decline last year. Such developments may cause somewhat greater food than farm product price gains.

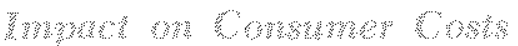

Consumers have been disturbed by the relatively sharp increases in food prices since late 1971. Food expenditures at home and away from home currently account for about 16 percent of disposable personal income, down from 20 percent in 1960. Still food remains one of the major items in the typical household budget.

Prices of raw farm products are exempt from price controls under Phase II of the price-wage control program. Thus, when farm product prices are bid up as a result of changed supply and demand conditions, the regulations permit processors and retailers to raise their prices to consumers and to maintain customary percentage margins. With the recent rise in food demand relative to supply and the resulting increase in food prices, some consumer groups have requested that price controls be placed on food products.

In reply to the pressure for such controls, the Secretary of Agriculture at the National Agricultural Outlook Conference made four points:

First: Farmers haven't caused inflation. The base period for government statistics is 1967 . Since that time the price of food has risen less than most of the other main components of the Consumer Price Index.

2U. S. Department of Agriculture, The Farm Index (February $1972)$, p. 23 .
In 1971, the American consumer bought her food supply, the best in history, with only 16 percent of her take-home income, the lowest percentage ever, in any country. And it is likely to go lower in 1972 without price controls on food.

There is no lack of food. Farmers have done their job. They have doubled the per capita supply of beef during the past two decades. The per capita food supply for 1972 is likely to be at least equal to that of 1971 . Farmers are now engaged in converting last year's abundant feed grain crop into meat, milk and eggs, and they will deliver the food if their markets are allowed to operate.

The reason for rising food prices is that consumers, with their increasing incomes, have bid these prices up. And consumers want more service with their food, which adds to price. Farmers are not to blame.

Second: Controls won't work. Controks were tried during the OPA days of World War II, as some of the older people here will remember. What was the result? Black markets, rationing, priorities, subsidies, allocations, regulations, and a whole host of gov ernment officials checking prices, weighing packages, and hauling people into court. And empty meat counters. What good does a consumer get from a low price for beef if no beef is available at that price? Price controls won't work for commodities as perishable, as seasonal and as varied in quality as food products. When the war was over we got rid of price controls on food, with widespread consumer support for their ending.

Some consumers, either too young to know or too forgetful to remember, may think they want controls. They should read history. It would be easier to learn the difficulties of price control for beet and pork by reading history than it would be to learn while standing in a queue at a halfempty meat counter.

Thind: Farm income should not be suppressed. Per capita income of farm people in 1972 is likely to average about three-fourths as high as average per capita incomes of non-farm residents. In 1972 , real ized net income from farming is likely for the first time to exceed the previous record of $\$ 17.1$ billion registered in 1947, twenty-five years ago. For what other majo: sector of the economy is an income equal to that of a quarter of a century ago thought to be so high that it needs to be suppressed by Govemment action?

Fourth: Agriculture is competitive. The main cause of the present inflation is the exercise of concentrated economic power by special interest groups. This power is exercised by labor union leaders who demand and receive unealistic wage increases for their members. Concentrated economic power is also exercised by industrial firms and by the service trades through administered pricing. The West Coast dockworkers, who have been receiving $\$ 7.76$ per hour, including fringe benefis, have just negotiated a wage increase that will, at the end of three years, bring their compensation, including fringe benefits, up to $\$ 9.94$ per hour. As anolber example, dung the year before the President's Economic Stabilization 


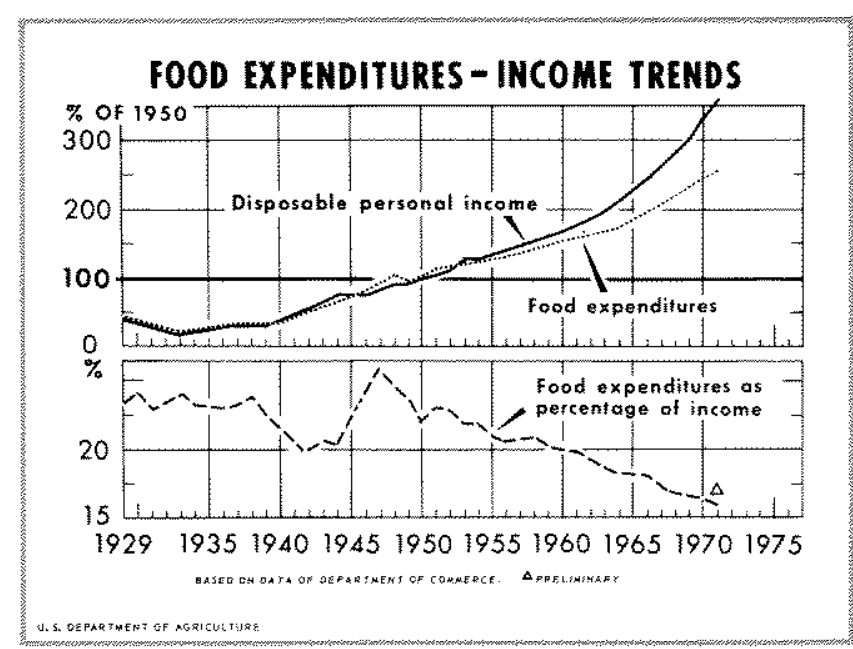

Program went into effect, the price of barbed wire increased 11 percent.

These goods and services are priced administratively, which means that competitive market forces are sharply restricted. The Economic Stabilization Program is properly focused on these particular sectors, which is where most of our present inflation originates.

In contrast, agriculture is highly competitive, sometimes harshly so, and is therefore not in need of control.

While the Secretary's view (that concentrated economic power caused the present inflation) is widely held, there are other explanations. ${ }^{3}$ Nevertheless, the data confirm his view that food prices have risen less than the average of other consumer prices in recent years. From 1964 to January 1971, the price of all consumer items increased at the annual rate of 3.6 percent, while food prices rose at the rate of only 3.4 percent. Food expenditures have been a declining portion of disposable personal income, dropping from 22.2 percent of such income in 1950 to 16.3 percent in 1971. Furthermore, food costs as a percent of total disposable income are expected to decline again in 1972, despite some further increases in food prices.

We have no evidence that laxge untons and business firms exercise greater power now than during the period 1953 to 1961 when the post-World War II inhation was slowed to a one percent rate, Monopolistic power of labor unions of of businesses can cause misallocation of resources and higher levels of unemployment, but it is doubtul that they have been a major cause of the current inflation. For example, the high rates of inflation during World War II and the Korean War were reduced by a slower rate of monetary growth. The morey stock from 1953 to 1961 rose only 1.4 percent per year and prices only 1 percent as measured by the wholesale and consumer price indices. This slower rate of irflation was achieved while a laroer percent of the labor force was unionized than is the case today. The share of nonagricul tural workers in unions aeclined from 34 to 28 petcent and of total workers from 25 to 23 percent during the period $1953-68$.

We likewise have no evidence of an increase in monopoly power in commodity markets. The fffty largest manufacturing

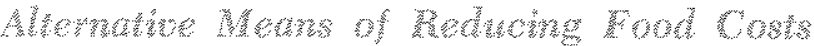

If the objectives of public policies are to reduce food costs and encourage economic growth, means are available which offer greater opportunities for success than the direct controls method. As pointed out by the Secretary of Agriculture, if supply and demand, including Government demand through price support operations, are in equilibritm at current prices, any reduction in price through direct controls will mean that consumers must face empty retail grocery shelves. Furthermore, any attempts at such control will require a large number of enforcers, taking manpower from the production of other goods and services, thereby reducing output and increasing inflationary pressure.

Other means of reducing food costs include such actions as freeing international trade and reducing our domestic farm price support and production control programs. Both methods would release manpower from the less productive to the more productive sectors of agriculture and the rest of the economy, thereby increasing total production of goods and services.

The immediate elimination of import restrictions on meat and sugar conld have an important dampening effect on domestic prices. An increase in meat imports would tend to reduce prices for frankfurters, luncheon meats, ground beef, and a variety of canned and frozen meat products. The removal of the sugar quota would result in a decline in domestic sugar prices of about $\$ .043$ per pound.* D. Gale Johnson, of the

fimns had 23 percent of value added in 1954 and 25 percent in both 1963 and 1966. Shipments accounted for by the largest four firms in each of twenty-two selected industries showed little change in concentration from 1947 to 1966. Furthermore, firms during this period experienced rising competition from manufacturing firms abroad.

In contrast to the view that imperfect labor and commodity markets are an important cause of inflation, research at this Bank indicates that the rate of money growth is the chief cause. In the recent inflation from 1965 to 1970 the money stock grew at a 5 percent rate, wholesale prices at a 3 percent rate, and the general price index at a 4 percent rate, Earlier inflations have likewise been associated with high rates of money growth.

The relatively long lag between slower money growth and its impact on prices has probably been disappointing with respect to the progress made in slowing the rate of inflation to date. Expectations based on past trends in prices and wages continue to provide inflationary momertum. It is during stuch periods that the monopoly powers of labor umions and some businesses are most noticeable, simce wages and prices often continue to rise despite under-utilization of resources. This momentum may extend over a period of three or four years, following a prolonged and relatively high rate of monetary expansion, as occurred in 1967 and 1968.

*Based on New York wholesale price differential between sugar for domestic and foreign use in November 1971. 
University of Chicago, reported at the recent Agricultural Outlook Conference that:

At the present time the sugar program imposes an additional cost of approximately $\$ 1$ bilion on consumers and taxpayers; this compares to total cash receipts from production of sugar cane and sugar beets in domestic areas of about $\$ 700$ million in 1970 . The cost to consumers is calculated as over and above the import cost of sugar and assumes that world market prices would increase if the U. S. increased its imports of sugar. It is obvious that the economic losses to consumers and taxpayers far exceed any net gains to producers of sugar in the United States; it is equally obvious that both those now producing and consuming sugar could be made better off by other arrangements, ${ }^{5}$

In addition to consumer gains from reduced import restrictions on farm products, any concessions we can obtain through bargaining with our world trading partners for reduced restrictions on farm exports will provide a greater market for our farm products. We probably have a relative production advantage in several major farm commodities. The exports of such commodities could be increased with reduced trade restrictions, and our farmers would gain by selling more of the products that they can produce with greatest efficiency.

A reduction in the nation's farm price support, production control, and related programs probably would not lead to a major change in output of farm products. Lower price supports would tend to reduce production. On the other hand, a relaxation of production controls, including the acreage rental program, would tend to increase production and production efficiency.

Domestic use of farm products would probably not increase significantly. Gains in production efficiency would lead to somewhat lower prices for farm products and food. Lower food prices would in tum lead to some upgrading of diets, thereby providing a marginal gain in domestic farm commodity and food consumption.

Commercial exports of farm products, however, would be expected to increase as a result of both somewhat lower average prices and a change in resource use to the production of commodities where we have the greatest comparative advantage. The lower prices would make our commodities more attractive abroad. By changing to the production of those products where our comparative advantage is greatest, both this nation and our trading partners

"Similar ineffeiencies in the U, S. sugar program were found by Thomas H. Bates in "The Long-Run Efficiency of United States Sugar Policy," American Joumal of Agricultural Economics (August 1968), pp. 521.535. abroad would reap the advantages of international specialization. On the other hand, a reduction in export subsidies would result in some decline in the exports of commodities shipped under these programs.

There is little evidence that the farmer is achieving substantial gains from the price support and acreage control programs. In fact, as pointed out so succinctly by D. Gale Johnson, the gains were in the form of a windfall to those who owned land when the programs began and offer little benefit once farm land prices and labor adjust to the new income flows.

The nature of agricultural production is such that efforts to create a cartel under guidance and subsidy from Washington will almost certainly lead to dis. appointing results. There is no way to restrict entry into agriculture. Thus if a program were to result in higher returns for agriculure through price supports and acreage restrictions, potential producers will attempt to enter the field. One way that this can be done is to buy land which has attached to it the right to produce the particular commodity. After a fairly short time land prices will be bid up and new producers will find that it is no more profitable to produce this particular crop than a number of others. This is not a hypothetical case, but is essentially what has happened in tobacco, where acreage controls, marketing quotas, and price supports have been maintained for two decades. ${ }^{6}$

6D. Gale Johnson, "Government and Agriculture: Is Agriculture A Special Case?" The Joumal of Law and Economics (October 1958), p. 128. For a further discussion of this topic see John F. Floyd, "Effects of Farn Price Supports" Joumal of Political Economy (April 1965), pp. 148-158. Floyd points out that the benefits of such programs take the form of a windfall, that is, the gain is once and for all. Thus, there is little advantage in these policies for the landless and for the person about to enter the industry. Armen A. Alchian and William $\mathrm{R}$, Allen in University Economics, 2nd ed. (Belmont: Wadsworth Publishing Company, Inc., 1968), p. 347, provide an analysis of the windfall aspects of our nationa farm program. $G, S$. Tolley in "Management Entry into $U . S$. Agriculture" American Jounal of Agricultural Economics (November 1970$), p .492$, suggests that the basic agricultural incone problem is one of low-level management being outmoded.

Alternative views relative to the farm price support and production control programs are presented by Willard $W$. Cochrane in The City Mans Guide to the Farm Problem (Minneapolis: University of Mimesota Press, 1965). Cochrane states, "If the full excess productive capacity of American farming of the early 1960 s were to be eliminated by lower prices, the decline in the level of farm prices conld be as much as 40 percent, and the decline in aggregate net farm income as much as 60 to 70 percent" (p. 126), Earlier however, in the same publication, Cochrane states, "Governmental price and income support has provided farmers with assistance and service, but the programs are costly, the longnin income results debatable, and the whole policy subject to intense controversy" (p. 11). Similarly, the National Advisory Commission on Food and Fiber in Food Needs and U. S. Agriculture in 1980, Technical Papers, Volurne 1 (August 1967), pp. 51, 52, points out the excess capacity in agrienlture and the major adjustments that would be necessary for a return to free market prices.

Both of these studies contend that in the absence of Government price supports and production controls, excess ca- 


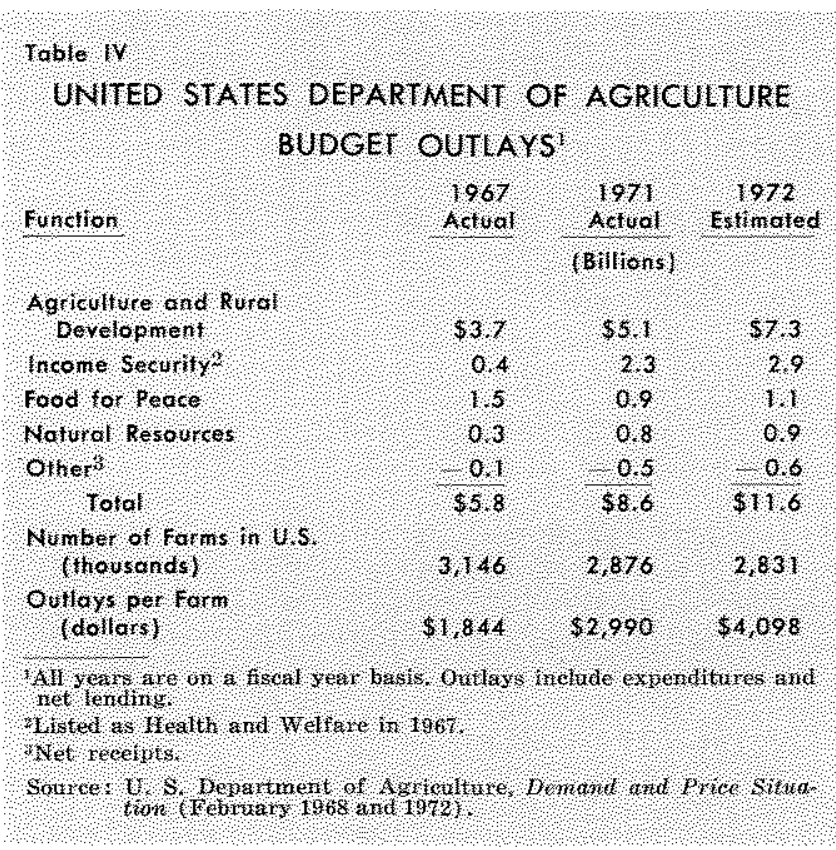

Another benefit from some dismantling of the farm program would be a reduction in Governmental exw penditures. Outlays of the U. S. Department of Agriculture for fiscal 1972 are estimated at $\$ 11.6$ billion, $\$ 3$ billion more than in 1971 and double the volume of these expenditures in 1967 (see Table IV). Such expenditures are expected to total $\$ 4,098$ per farm in 1972,37 percent more than a year earlier and more than double that of 1967. Not all of these costs are associated with the objective of larger farm incomes.

pacity will have an unfavorable impact on farm incomes. Over the longet run, however, as pointed out by many economists, agricultural capacity adjusts to income changes Higher returns to resources in agriculture relative to resources in other sectors provide incentive for resources to move into farming. Conversely, reduced incomes in agriculture lead to reduced capacity. See Zvi Griliches, "Estimates of the Aggregate U. S. Farm Supply Function," Joumal of Fam Economics (May 1960), pp. 282-293; Lowell E. Gallaway "Mobility of Hired Agricultural Labor: 1957-1960," Joumal of Farm Economics (Febuary 1967), D. 47; Larry Langemeier and Russell G. Thompson, "Demand, Supply, and Price Relationships for the Beef Sector, Post-World War II Period," Joumal of Farm Economics (February 1967) p. 174; Randolph Barker, "Appropriate Methods for Estimating the Short-Run Elasticity of Supply for Milk, Journal of Farm Economics (August 1965), p. 841; A. J. Raymer and Keith Cowling "Demand for Farm Tractors in the United States and the United Kingdom," American Joumal of Agri cultural Economics (November 1968), pp. 896, 906; and Lither G. Tweeten and C. Leroy Quance, "Positivistic Measures of Aggregate Supply Elasticities: Sone New Approaches," American Joumal of Agricultural Economics (May $1969)$, p. 352 .
Agricultural research and extension work, soil conservation, forestry, and a number of the traditional functions of the USDA would remain if the price support, production control, and related expenditures were removed. But, the total costs of these traditional functions of the Department probably don't exceed 10 percent of its current budget. ${ }^{7}$ The major portion of its expense could thus be eliminated in the absence of the price support and production control objectives.

\section{*.}

In summation, the outlook is for higher farm incomes in 1972. Gross farm income will probably rise $\$ 3$ to $\$ 3.5$ billion from a year earlier, largely reflecting higher returns from livestock products and increased Government payments. Net farm income may rise $\$ 1.5$ to $\$ 2$ billion, the sharpest year to year gain in recent years, and average income per farm is expected to exceed $\$ 6,100$. Prices for farm products will also average higher than last year.

Food prices will average higher than a year ago, reflecting increases in both processing and marketing margins and farm product prices. The increases have resulted in pressure for price controls on food. More efficient means of reducing food prices are to be found in freeing up international trade and reducing farm production controls and price supports. Any attempt to directly control food prices while such programs exist would involve one arm of the Federal Government supporting farm prices and another arm attempting to depress them.

The removal of import barriers would result in lower prices for a number of important food items, and to the extent that foreign nations reciprocate, markets for our farm products would be increased. Reduction of the price supports and production controls would result in more efficient use of national resources, reduced Federal cost, and offer greater assurance of success at reducing food costs than attempts at direct controls. A reduction in the production control and price support programs would provide incentive for resource adjustments within the farm sector and between the farm and non-farm sectors, thus increasing the cutput of all goods and services.

7D. Gale Johnson, "Government and Agriculture," p. 122. 